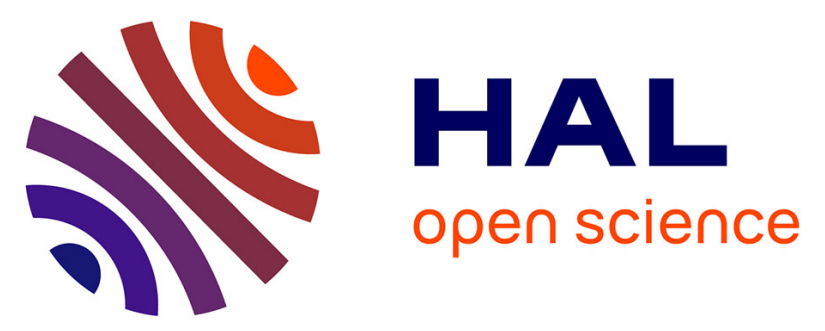

\title{
Participatory analysis for adaptation to climate change in Mediterranean agricultural systems: possible choices in process design
}

N. Faysse, Jean-Daniel Rinaudo, S. Bento, A. Richard-Ferroudji, M. Errahj, M. Varanda, A. Imache, M. Dionnet, D. Rollin, Patrice Garin, et al.

\section{To cite this version:}

N. Faysse, Jean-Daniel Rinaudo, S. Bento, A. Richard-Ferroudji, M. Errahj, et al.. Participatory analysis for adaptation to climate change in Mediterranean agricultural systems: possible choices in process design. Regional Environmental Change, 2014, 14, p. 57 - p. 70. 10.1007/s10113-012-0362-x . hal-00958442

\section{HAL Id: hal-00958442 \\ https://hal.science/hal-00958442}

Submitted on 12 Mar 2014

HAL is a multi-disciplinary open access archive for the deposit and dissemination of scientific research documents, whether they are published or not. The documents may come from teaching and research institutions in France or abroad, or from public or private research centers.
L'archive ouverte pluridisciplinaire HAL, est destinée au dépôt et à la diffusion de documents scientifiques de niveau recherche, publiés ou non, émanant des établissements d'enseignement et de recherche français ou étrangers, des laboratoires publics ou privés. 


\title{
Participatory analysis for adaptation to climate change in Mediterranean agricultural systems: making use of possible choices in process design
}

\author{
Faysse, N.1,2, Rinaudo, J.-D.3, Bento, S.4, Richard, A.5, Errahj, M.2, Varanda, M.6, \\ Imache, A.7, Dionnet, M.7, Rollin, D.5, Garin, P.5, Kuper, M.1,8, Maton, L.3, Montginoul, \\ M.5 \\ ${ }_{1}$ Centre International de Recherche Agricole pour le Développement, France \\ ${ }_{2}$ National College of Agriculture of Meknes, Morocco \\ ${ }_{3} B R G M$ (French Geological Survey), France \\ 4 Socius, Technical University of Lisbon, Portugal \\ ${ }_{5}$ Cemagref, France \\ ICS Social Science Institute, University of Lisbon, Portugal \\ 7 LISODE, France \\ 8 Institut Agrovétérinaire Hassan II, Morocco
}

\begin{abstract}
There is an increasing call to define adaptation measures to climate change at a local level, based on foresight analyses undertaken with actors. However, organizing such analyses in a participatory way faces many challenges, in particular because actors may not judge the climate change issue as being part of their more urgent concerns. The present study examines the choices made to design and implement participatory foresight analyses to explore adaptation options for coastal regions in France, Morocco and Portugal. In these areas of intensive agricultural use of groundwater, aquifers are at risk or in current situation of overexploitation. In all cases, debating climate change with local actors was not granted from the outset, especially because of a pregnant agricultural crisis. The study analyses the main issues that researchers had to address to design the participatory processes: regarding whether to avoid or prepare dialogue between differing actors, on which basis should participants be selected and how to get them involved, how to enable discussion over issues that actors may not see of interest at the outset, and how to design and use scenarios. The analysis focuses on the choices made, the elements taken into account for these choices and their main results. Different approaches were explored that led to widen the frame of discussed issues to encompass the future of agricultural activities and water management. Most invited actors participated and were able to either comment on scenarios proposed by researchers or build ones during the workshops. Adaptative strategies were discussed at various levels, from farming practices to aquifer management. This comparative study shows the possibility and relevance of such participatory analyses in situations initially not favorable for such work. This was made possible thanks to a detailed initial analysis of the context, and in particular the actors, the institutions, the available data, and the way actors considered issues related to water resources and agriculture. This analysis enabled to inform the choices made in order to craft specific processes based on local circumstances.
\end{abstract}

Key words: Climate change adaptation -foresight analysis - groundwater - participatory processes 
Author-produced version of the article published in Regional Environmental Change, 2014, N${ }^{\circ} 14$, p.57-70

The original publication is available at http://link.springer.com/article/10.1007\%2Fs10113-012-0362-x

Doi: 10.1007/s10113-012-0362-x

\section{Introduction}

The participation of local actors in the reflection about ways to adapt to climate change has often been put forward as a cornerstone to improve their adaptive capacities to such change (Commission of the European Communities, 2007; Lim et al., 2005). The numerous experiments that organized such participation of actors used - and often crafted - a wide diversity of methods. This diversity resulted from the numerous choices that the teams in charge of the participatory process design and implementation made, taking into account several elements, such as the status of the process (for instance, more research or decision-making oriented).

These choices were also made to address several challenges related to the actors, the available data and the institutional context. Some of these challenges are not specific to climate change. Actors may for instance decide that they are better off outside than inside such participatory processes (Eakin et al., 2007; Kowalski et al., 2009; Loibl and Waltz, 2010). Other challenges are more specifically linked to climate change. Firstly, getting public involved in discussing this issue faces constrains both at individual level, such as fatalism, or at the collective one, with for instance worry of free rider behaviors (Lorenzoni et al., 2007). Secondly, it may be difficult to exchange with actors about climate change because of uncertainties in the models results, especially at local level (Few et al., 2007). Thirdly, there may be a gap between the stakes perceived by local actors and those linked to climate change. Indeed, time horizons may be completely different: economic actors usually pay much more importance to the short term, while simulations of climate change models generally deal with periods between 2050 and 2100. Climate change and even climate variability may not appear as a key issue for these actors (Kock et al., 2007; Mertz et al., 2007; Shisanya and Khayesi, 2007). The horizon of climate change models may thus appear to be too far away for actors to feel at ease to discuss possible scenarios. Fourthly, institutional context may not be propitious for such work, for instance there may be limited capacities of public institutions to implement decided-upon adaptation policies (Meenawat and Sovacool, 2011).

Accounts of participatory processes to reflect on adaptation to climate change generally focus on what was found in terms of adaptation strategies. They more rarely encompass an evaluation of the implementation of the process per se, and in particularly the way the implementation team faced and addressed some of the above-mentioned challenges. A much more limited number of studies (for instance, Patel et al., 2007) made explicit the way they initially took into account these challenges while designing the process. In the latter case, they generally focused on cognitive issues, i.e., the how to support actors' understanding of climate change dynamics and impacts. Among the latter, many experiences were based on a single case, which may provide only indirect guidance to reflect on which elements the team took into account to design of the participatory process.

The paper analyses the experience of three research teams aiming at organizing reflections with local actors regarding adaptation to climate change. It assesses the way the teams adapted an initial common framework to craft specific process based on local circumstances and the elements these teams take into account when making such choices. The experience took place during the Aquimed research project (2008-2010), which aimed at developing methods to support local actors in undertaking foresight analyses and assess adaptive strategies of management of groundwater resources and uses, in the perspective of climate change. The project worked on three study sites in 
France, Morocco and Portugal, in the Mediterranean area, which is predicted to be a hotspot of climate change in the future (Arnell, 2004) ${ }^{1}$.

All these sites were coastal regions, where agriculture had an intensive use of groundwater, and where aquifers were at risk or in current situation of overexploitation. This made such areas especially vulnerable to climate change impacts since in all study sites, climate change models predict a decrease in future rainfall patterns (Somot et al., 2008), notwithstanding other changes (wind, frost, etc.). This evolution could lead to both decreased aquifer recharge and increased use of groundwater by farmers. In the agricultural sector, pathways for adaptation may range from farm level (mainly changes in agricultural practices and crops), to the agricultural sector at regional level (e.g., more water productive agri-food supply chains), and to improved governance of surface and groundwater resources.

In these three sites, discussing adaptation to climate change with local actors did not appear as granted from the outset. First, the agricultural sector was in crisis, therefore there was the challenge of how to engage farmers, who had to solve many short-term issues, in discussing long-term ones. Second, in the three cases, there was no control over water withdrawn from the aquifer, and very limited discussions among local actors took place regarding the eventuality of such management in the future. Apart from these similarities, the study sites showed many differences, regarding in particular the degree of aquifer overexploitation and the organizational set-up for water resource management.

While the project was implemented in each site by a specific research team, these three teams collaborated and exchanged all along the project. At the outset of the project, the researchers decided that, while they had a common general objective and a common framework, they would give themselves flexibility in the design and implementation of the participatory processes so as to take into account their initial assessment of the socio-economic conditions of actors and the institutional settings.

In order to design the participatory research processes, the teams made choices with regards to four main issues: i) whether to avoid or prepare dialogue between differing actors ${ }^{2}$; ii) on which basis should participants be selected and how to get them involved; iii) how to enable discussion over issues that actors may not see of interest at the outset; and iv) how to design and use scenarios. These four issues were separated for clarity and analytical purposes, but they are linked and have mutual influence. For instance, the actors invited will partly determine which themes will be discussed and how they will be addressed. Moreover, their understanding of projected climate change impacts may have an impact on the importance they give to the issue. Other issues were considered, such as the spatial scale of scenarios, but are not analyzed here.

\footnotetext{
${ }^{1}$ The Portuguese and Moroccan study areas border the Atlantic Ocean, but they may be considered as part of the Mediterranean area, in terms of climate characteristics, ecosystems, agriculture increasingly competing with tourism and urban development for land and water use, etc. Moreover, models of climate change consider these areas as part of the Mediterranean zone.

${ }^{2}$ We use here the term of "actor" since, as seen above, local actors may not consider themselves as having stakes with regards to climate change, therefore the term of "stakeholder" should not be considered as selfevident.
} 
The paper is organized as follows. The studied sites and the main elements of the participatory processes are presented, followed by a brief presentation of results in terms of identified adaptation policies. This paper does not provide a detailed account of each case study and of the results of the participatory processes, as they are presented in Bento el al. (2012), Faysse et al. (submitted), Maton et al. (2010), Richard-Ferroudji et al. (2011), Rinaudo et al. (2012) and Rinaudo et al. (submitted). The next section analyzes the choices made according to the four above-mentioned issues in the three study sites. For each issue, choices of other participatory research processes for climate change adaptation are first presented. Then, each subsection follows with the initial situation that researchers assessed with regards this issue, the choices that were made, and some of the results of such choices. The discussion part underlines the common elements that the teams took into account to set up the participatory processes, and what was learnt in terms of engaging with the increasingly present request to organize participatory reflection to define climate change adaptation.

\section{Overview of participatory research processes}

\subsection{Case studies}

In France, the Roussillon Plain aquifer is located along the southwestern part of the Mediterranean coast. The aquifer present in this area is intensively used for drinking water purposes, for tourism related activities and by agriculture. The decline in the water tables, which has been observed over the last 30 years, is expected to continue as the population keeps growing and the farming sector progressively abandons surface canal irrigation systems in favor of wells and boreholes. In response to these increasing pressures on groundwater, the local authorities and government agencies have actively supported the establishment of a participatory forum, called the Local Water Commission, which brings together all major actors to debate on actions to be implemented as part of a formal Local Water Management Plan. The catchment management agency attempts to set up individual water meters and to cap total groundwater withdrawals. Farmers are well-organized and represented in the Local Water Commission. They contest the existence of a groundwater management problem and are rather reticent to establishing formal groundwater allocation mechanisms (Montginoul and Rinaudo, 2009).

The Querença-Silves aquifer is considered the most important aquifer system of the Algarve Region in the South of Portugal. The aquifer is used for irrigation, for drinking water supply and for tourism. Use of the aquifer has not resulted in overdraft yet and groundwater table decreases only took place in severe drought periods. However, expected increases in groundwater demand for domestic and tourism purposes as well as a reduction of recharge may cause overexploitation (Stigter et al., this issue). In 2009, the local catchment management agency started developing a plan as part of the process to implement the Water Framework Directive. This plan, which will be the base for the management of surface and ground water, had a participative, but weakly carried out, component. Indeed, such issues were not traditionally discussed in public. Even less usual was the participation of actors in public policy design, in fact both administration and actors were giving their first steps as far as participation processes go. 
The Coastal Chaouia region is situated south of Casablanca on the Atlantic coast of Morocco. Since the 1970s, groundwater has been used intensively for irrigation (Berrahmani et al., submitted). Groundwater overuse led to sea water intrusion in littoral land and decreasing groundwater levels in in-land areas. Groundwater stress has been the prime factor that led the region from intensive export-oriented agriculture to a situation of crisis. Two catchment management agencies are in charge of the area, but with very limited capacity to intervene. No groundwater management mechanism is implemented or planned. In 2009, a Regional Agricultural Plan was defined that contemplated bringing surface water to part of the area. This plan had been set up by the administration, with very limited participation of farmers. Similarly to the Querença-Silves case, the few existing farmer organizations were not formally involved in decision-making over water resources and agriculture.

The three cases have in common that agriculture, while being in crisis, is pinpointed as the sector that most needs to reduce its groundwater pumping. Indeed, in the Chaouia, agriculture is almost the unique user of groundwater. In the two others cases, while the drinking water sector is also a major user of water, it is considered as having priority over the agricultural sector. This said, the three cases differ in four major aspects that impacted on the way the participatory research processes were designed (Table 1). In the Roussillon and Querença-Silves areas, farmers do not consider water access and climate variability as currently being major constraints. Climate change and the necessity to adapt to it are thus seen as a remote issue. By contrast, Chaouia farmers place groundwater scarcity and salinity as the most important constraints, and consider climate variability as having a determining impact on groundwater quantity and quality.

Table 1. Main differences in the study sites

\begin{tabular}{|c|c|c|c|}
\hline & Roussillon & $\begin{array}{l}\text { Querença- } \\
\text { Silves }\end{array}$ & Chaouia \\
\hline Stress over groundwater resources & Weak & No & Strong \\
\hline $\begin{array}{l}\text { Organizational set-up for } \\
\text { groundwater management }\end{array}$ & Initiated & Planned & No plan \\
\hline $\begin{array}{l}\text { Existence of official agricultural } \\
\text { development scenarios }\end{array}$ & No & No & Yes \\
\hline $\begin{array}{l}\text { Farmers' organizations presence in } \\
\text { the area and role in public arenas }\end{array}$ & $\begin{array}{c}\text { Presence in official planning and } \\
\text { management platforms, but } \\
\text { weak leverage over decision- } \\
\text { making }\end{array}$ & Weak & Weak \\
\hline $\begin{array}{l}\text { Farmers' perceptions of an existing } \\
\text { groundwater scarcity }\end{array}$ & No & No & Strong \\
\hline
\end{tabular}

\subsection{Implementation of the workshops}

A broadly similar series of workshops took place with farmers and public organizations in the three cases (Fig. 1). The participatory processes did not encompass all possible dimensions of climate change adaptation and focused on three of them: agricultural practices at farm level, the types and organization of agriculture at regional level and collective water management. 
In the Roussillon site, three series of workshops were organized with each of three groups of farmers. In the first series, participants were invited to comment four scenarios of regional agriculture development by 2030. The second series of workshops dealt with scenarios of future water scarcity levels and agronomic impacts of climate change in 2050, in order to discuss possible actions at farm level that may be undertaken to improve adaptive capacities to such changes. In the last series, three scenarios of groundwater management, also by 2050 , were discussed. Similar work was organized with staff from public organizations in charge of agriculture and water management. The process ended with a meeting involving farmers and public organizations. A similar process was followed in the Querença-Silves site, with an additional initial workshop with farmers to assess past and current trends in the agricultural sector. This provided information for the design of scenarios in workshop 1 and $1^{\prime}$ (see Fig. 1). The workshops with public organizations also encompassed environmental NGOs, hydrogeologists and a public agency of tourism.

In the Chaouia, the first series of workshops with three groups of farmers were dedicated to the diagnosis of current agricultural dynamics in their villages. The second series was dedicated to designing scenarios of agricultural development at village level, based on assumptions regarding identified key driving factors. A third workshop was held in common with representatives of the three farmers' groups to share previous work and build common scenarios. Similar work was done with public organizations, which mainly encompassed staff from the Department of Agriculture. These preparatory workshops led to a common regional meeting where participants presented past works.

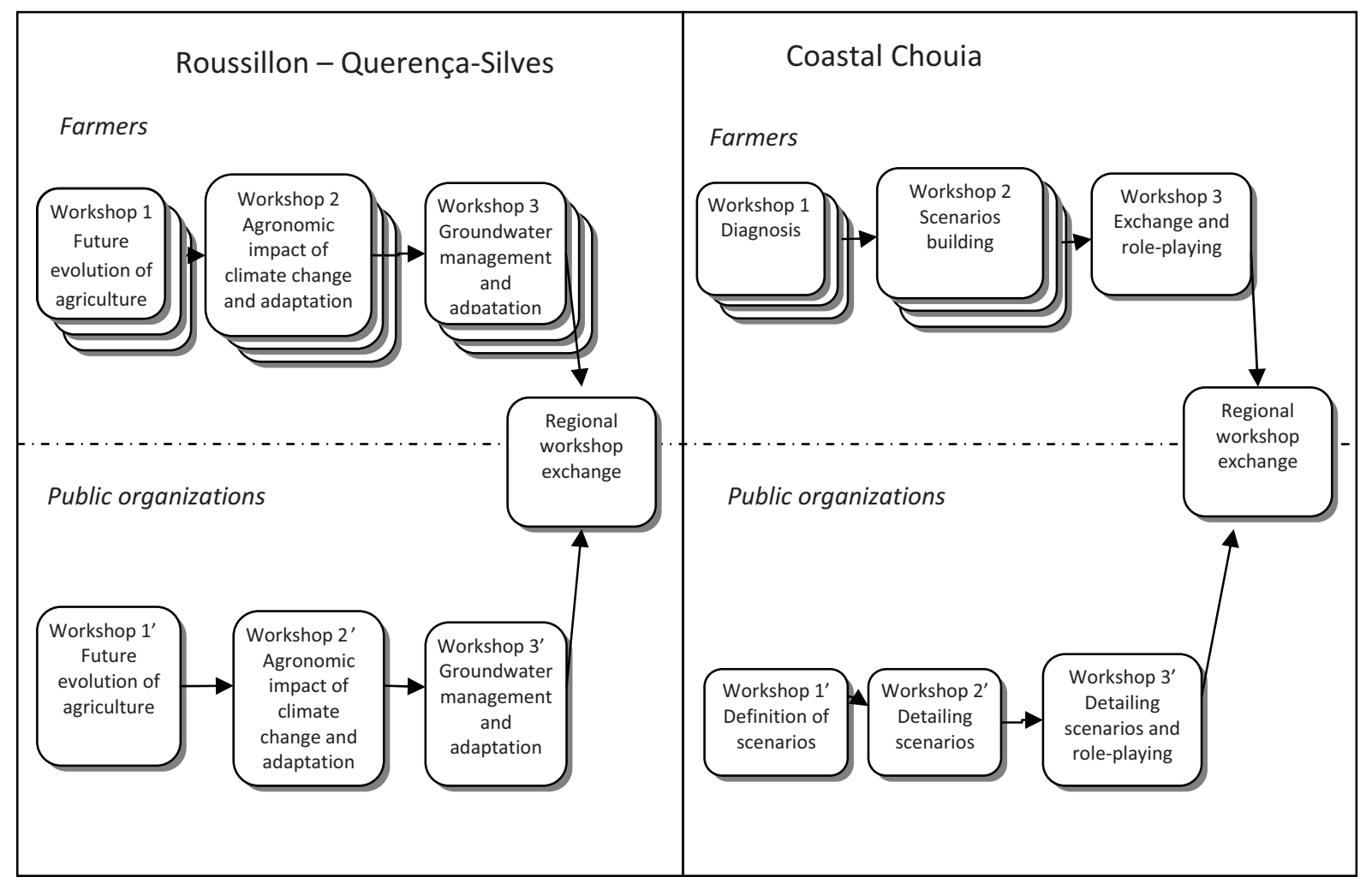

Fig. 1. Workshops organized during the participatory research processes. 
Author-produced version of the article published in Regional Environmental Change, 2014, N¹4, p.57-70

The original publication is available at http://link.springer.com/article/10.1007\%2Fs10113-012-0362-x

Doi: 10.1007/s10113-012-0362-x

\subsection{Main results and outcomes of the processes}

The main results of the workshops are briefly presented, as well as actors' evaluation of the process, and the outcomes of the research initiative (see each case study account for a detailed evaluation). Firstly, in the Roussillon and Querença-Silves cases, farmers expressed that existing adaptive capacities at farm level were sufficient, and both farmers and public organizations characterized the qualities, drawbacks and likeliness of agricultural development and groundwater management scenarios. Impacts of climate change were calculated for two scenarios. Moreover, some farmers of Roussillon said the workshops helped them preparing future decisions related to, for instance, the installation (or not) of an irrigation system in their farm and the choice of varieties of vine to be planted in the coming ten years. In the Chaouia case, actions for improved resilience to the groundwater crisis and climate variability were jointly identified in the final workshop. The interest of some agricultural activities that past public policies did not consider as relevant for the region was put forward, such as dairy farming. Secondly, actors were generally satisfied with the reflection process, both because of the ideas they learnt and because, in the Chaouia and Querença-Silves cases, it provided them with the opportunity to present their ideas to other actors. Several Moroccan farmers however expressed that the process would be beneficial inasmuch as the ideas discussed during the last workshop would eventually be implemented. Thirdly, in Roussillon, some institutional representatives said they later used the scenarios for supporting discussion in different groups at the local or even regional level. The Chamber of Agriculture decided to launch its own official foresight analysis with regards to the impacts of climate change. By contrast, in the Chaouia and QuerençaSilves cases, and based on contacts held some months after the process, there was no visible incorporation of the ideas debated during the final workshops in public organizations' agendas and methods.

\section{Four common issues in designing the processes}

\subsection{Avoiding or preparing dialogue between differing actors}

In situations where actors have either tense relations or have limited experience of exchanges, research-led processes may be implemented with separate groups of actors (Lövbrand et al., 2009). The team may also work with actors during initial workshops held separately, in order to build capacities, so that later on a joint workshop is held where social learning may take place (Daniell et al., 2011; Imache, 2009).

The Aquimed cases differed much in this issue, although they all formally involved initial workshops held separately with farmers and public organizations, followed by a workshop involving all actors. In the Roussillon, the Local Water Commission was an officially existing platform where farmers and public organizations had theoretically the opportunity to discuss water management. Therefore, there was no demand from actors to have another forum to discuss among them. Moreover, farmers were in practice sidelined in such commission, and farmers' organizations and the catchment management agency were already engaged in tense relations. The team considered that there was 
thus a risk that strategic behavior may limit opportunities for frank discussion in workshops involving different actors. The process was thus designed and presented as mainly about organizing a dialogue between actors in similar positions (e.g, between farmers) and an exchange between these actors and researchers. The last workshop with both farmers and public organizations was focused on a presentation of the results of previous workshops and subsequent discussion. The initial workshops held separately were however not specifically geared to prepare an exchange between actors during this last workshop.

In the Querença-Silves and Chaouia cases, farmers and public organizations in charge of agriculture and water resource management were not used to talk to each other. Therefore, the teams emphasized the preparation of the groups to the last meeting and in particular they focused on supporting farmers' capacities to interact with public organizations. For instance, the Querença-Silves team provided them with information on the aquifer resources and uses. The Chaouia team helped farmers prepare their own assessment of the current situation, of evolution scenarios and of actions to make happen the preferred scenario. Moreover, for both farmers and public organizations, a role playing session was organized during the third workshop in order to improve each other understanding, so as to prepare for the last meeting. Farmers played the roles of local public organizations, so as to learn their missions and means. Public organization staff played the role of farmers, in order to better understand their constraints and their margins for maneuver.

\subsection{Group composition and mobilization of participants}

A frequent issue in participatory process design is how to compose the groups of actors invited and how to make sure that these actors would be interested to come. With regards to getting actors interested in coming, other research teams either made the invitation through a locally wellrecognized actor (McCrum et al., 2009) or took time to build personal links between the researchers and the actors (Thompkins et al., 2008). Workshop location and schedules were also carefully chosen so as to facilitate the venue of actors (Patel et al., 2007).

In the Aquimed project, the teams sought to obtain a diversity of farmers participating in the workshops in the three cases. In the Roussillon, three groups were constituted, one of farmers close to the Chamber of Agriculture, the second of farmers belonging to the same organic production groups, and the third of farmers recently installed. In Querença-Silves, two groups were designed based on a geographical criterion, which was coherent with differences in the type of farming systems. In the Chaouia, the three groups came from the distinct sub-areas defined by the researchers, based on both the water-related problems (areas affected by salinity or water scarcity) and the farming systems.

In the Chaouia, in order to prepare groups of farmers to participate actively in the last workshop with public organizations' representatives, the researchers decided to work with groups of farmers that came from the same villages and already knew each other. Such groups could more easily achieve a common analysis of problems, scenarios and possible solutions, and their representatives could thus feel more at ease to present their work. By contrast, in both the Roussillon and Querença-Silves cases, the teams did not invite farmers that necessarily knew each other, since farmers' groups were 
not expected to present a common position during the last meeting. Therefore, the workshops with farmers in these two cases aimed to enable an exchange of viewpoints and experiences without the need to define a common position.

Getting the participation of actors was not granted at the outset of the process. In the Roussillon site, farmers considered the "water issue" as more linked to the strengthening of regulations imposed by the catchment management agency than to current or future water scarcity. Moreover, many farmers considered themselves officially represented in the Local Water Commission, thus they did not understand why they were asked to participate. In the Chaouia case, farmers did not expect much from the state, which stopped most of its intervention programs in the area 15 years ago. Moreover, just before the inception of the Aquimed project, vegetable farmers had spent much time discussing with the Department of Agriculture about reinitiating cooperation for producing vegetables for export, with no success. These farmers were tired of meetings with public organizations and skeptical about the outputs of the research project. Large-scale farmers were also not interested to participate, as they had already privileged contacts with local antennas of the Department of Agriculture. By contrast, in the Querença-Silves case, farmers were keen to participate, but some public organizations, such as the local drinking water company, did not show much interest in the process.

In order to prepare the process, the teams undertook many initial contacts with farmers and public organizations and maintained them during the whole process. This enabled to build and nurture trust and facilitated attendance of invited actors. In order to build trust, the Chaouia team also supported the reflection over a project of dairy collection cooperative with one of the groups. Moreover, workshop locations were also carefully chosen, for instance places considered as "neutral" were chosen when workshops involved both farmers and public organizations. Workshop schedules were also defined to facilitated attendance. For instance workshops with Roussillon farmers took place in the evening, after the latter had completed their work in the farms.

Most of invited actors eventually participated and remained present all along the process. Indeed, staff of public organizations found it interesting to discuss long term issues and to be involved in a participatory experiment. Farmers also appreciated to discuss the evolution of their territory and to get an opportunity to voice their points of view to public organizations. Some actors remained however outside the process, such as large-scale farmers in the Chaouia and some public organizations in Querença-Silves.

\subsection{Enabling discussion of issues that actors may not initially consider of interest}

Many participatory processes aimed to introduce themes related to climate change that may be initially considered by actors as too theoretical or too distant from their most urgent concerns. In cases where actors, and in particular small-scale farmers, were already vulnerable to climate variability, the researchers often considered the latter as a proxy - i.e., a concept that enables to indirectly tackle the issue - for future climate change (Morton, 2007). Indeed, improving the adaptive capacity to current climate variability may enable to be more prepared for future climate change. In 
such approach, climate change models may be even not mentioned in the workshops (Valkering et al., 2010). Such approaches led to propose a more explicit connection between the climate change adaptation goal and the one of disaster risks reduction (Mitchell et al., 2010).

In the Aquimed processes, interviews carried out initially suggested that many actors - farmers in particular - would not consider relevant discussing climate change and water management issues. It was therefore considered as necessary to embed this discussion in a wider appraisal of future evolution of agriculture in order to motivate actors to participate in the process. In particular, Roussillon farmers had stated that there was little no point in discussing impacts of climate change on agriculture since agriculture would likely have disappeared by the time these impacts are visible. Moreover, most farmers in the three cases did not perceive major changes in the climate (Bento et al., 2009), which indeed take place in a lap of time longer than a generation (see Hulme et al., 2009). Despite this, farmers of the Roussillon and Querença-Silves areas were well exposed to the issue through the media. By contrast, most interviewed farmers in the Chaouia had not heard about climate change. Finally, a decrease in water resources, and especially groundwater, was among the main projected impacts of climate change. However, groundwater management had never been discussed in the Chaouia and Querença-Silves cases, and was the subject of deep conflicts between farmers and the catchment management agency in the Roussillon one. Roussillon and QuerençaSilves farmers did not judge groundwater management as an important issue for their own activities.

In order to be able to discuss these issues with actors, the three teams chose agriculture as the initial theme to be discussed with farmers and public organizations. Indeed, the researchers made the assumption that, in such situations of agricultural crisis, starting with agriculture would enable farmers to discuss more optimistic scenarios, to imagine future in a more positive mind, and, in the Roussillon and Querença-Silves cases, that this would help farmers being motivated to discuss longterm climate change prospects. This entry point was also considered as useful to build the relationship with farmers. In the Roussillon and Querença-Silves cases, starting with agriculture and its future showed the importance that researchers paid to this activity, and as such helped differentiate such work with the one of public organizations in charge of water resource management. Farmers appreciated this approach since, for once, they were not reduced, in the water debate, as mere water consumers and polluters. Farmers indeed often put forward that they complied with a social role that was much broader than the one of being an economic actor using water, and that such role was not sufficiently recognized in the water resources management arenas.

In the Chaouia site, during the first workshops, farmers and public organizations were initially invited to talk about the present and future of agriculture. Participants selected on their own the key current drivers of change that should be considered for the design of scenarios in the following workshops. Given the fact that the region was living a groundwater crisis, the research team made the assumption that water would emerge as one of the key drivers of change. Indeed, the three farmers' groups selected the water constraint (water salinity or scarcity, depending on the area) as the most pressing one. Public organizations also put forward water resource dynamics as a major evolution factor.

In the Roussillon and Querença-Silves sites, after having discussed the future of agriculture in workshops 1 and 1', the researchers prepared information describing past and future climatic changes as well as an analysis of agronomic impacts of future changes in temperature, rainfall and 
irrigation water requirements and water resources availability. The underlying assumption was that this information that would be of more direct relevance for farmers than mere data on climate change. Efforts were made to present these data in an easily understandable format. Farmers felt at ease to comment on such projected impacts, though Roussillon farmers pointed out that the presented data did not include future evolution of wind and frost distribution, which was according to them an important element in their farming practices and crop choices. In the Chaouia, the future trends on rainfall and groundwater balance as predicted by climate change models were presented only to public organizations, during workshop 2'. The Chaouia team decided not to present the results of climate change models to farmers because the latter plan their actions on a short term basis and it was assumed that farmers would not be interested in discussing possible rainfall evolution patterns 30 years ahead. Moreover, following Morton (2007), since farmers were already very vulnerable to rainfall variability, this variability could be considered as a proxy for climate change.

With regards to groundwater management, the Roussillon farmers knew that a process to regulate groundwater use had started in their region, and the Querença-Silves ones knew that such a process was about to be initiated. Even if Roussillon farmers were officially against such regulation, the idea that some form of management would sooner or later take place was making sense to them. Farmers' acceptation of discussing groundwater management was facilitated by defining groundwater management scenarios in a long-term future, i.e., by 2050. The discussion over groundwater management scenarios took place in these two cases at the end of the process, when farmers and researchers had already worked together at least twice and knew each other. Such discussion also made sense to farmers because at this point of the participatory process they could clearly envision a future of water scarcity as a consequence of climate change. In the Chaouia, firstly farmers considered that groundwater overuse had much less impacts than drought on groundwater dynamics and that each farmer was fully entitled to use groundwater available in his land as he wished. Secondly, public organizations did not show any willingness to get into groundwater management. In such a context, and since also the discussed time frame was much shorter (approximately 2020), the team decided not to impose such issue, and the scenarios were not about regulating groundwater use but rather on how to best adapt to the groundwater crisis.

\subsection{Design and use of scenarios}

\section{Contents and status of scenarios}

Participatory methods to discuss climate change are examples of more general participatory foresight methods, which may be typified into different schools (Rounsevell and Metzger, 2010). All such methods may be placed along a gradient with regards to the chosen balance between the type and amount of information that the researchers bring to be discussed with participants and the type and amount of information that actors share or create during the workshops. At one extremity of such gradient, participants are invited to define adaptation options after having been presented climate change and socio-economic scenarios prepared in advance. Such approach allows the researchers to carefully craft the scenarios and in particular to incorporate climate change models simulations (Eakin et al., 2007; Poumadère et al., 2008; Thompkins et al., 2008). It also allows the 
Author-produced version of the article published in Regional Environmental Change, 2014, N¹4, p.57-70 The original publication is available at http://link.springer.com/article/10.1007\%2Fs10113-012-0362-x Doi: 10.1007/s10113-012-0362-x

teams to prepare the way to communicate and assess climate change models simulations with participants (McCrum et al., 2009). In the middle of this gradient, Patel et al. (2007) provided broad socio-economic scenarios at Mediterranean level to support actors' exploration of scenarios at local level. At the other extremity, scenarios are completely built with actors during the workshop. This latter approach aims to foster actors' capacity to reflect on their environment based on their own knowledge and to explore the future of their region (Gidley et al., 2009; Imache et al., 2009).

The Aquimed teams chose different positions along this gradient. In the Roussillon and QuerençaSilves cases, apart from the initial diagnosis workshop in Querença-Silves, the teams always initiated the workshops by presenting information prepared by researchers in advance. The presented scenarios with regards to agricultural development (workshops 1 and $1^{\prime}$ ) and to water management (workshops 3 and $3^{\prime}$ ) were based on regional data and personal interviews. In the workshops 2 and 2 ', this information was mainly the results of models of climate change downscaled at local level (future temperatures and precipitations) and scientific analyses of possible agronomic and hydrological impacts of such changes (e.g. expected reduction in river discharges and increases in irrigation water requirements). Actors were invited to criticize and possibly "deconstruct" such information and scenarios. There was no attempt to have participants jointly agreeing on reformulated scenarios during the workshops (although this happened in some workshops on water management in Roussillon, leading to a synthesis scenario, but this was not initially planned). The two teams made such choice because they had access to data, and because both teams estimated that organizing a participatory design of scenarios would require more time than participants would be willing to spend in the frame of a research project not likely to lead to important policy decisions.

In the Chaouia, the researchers decided to identify drivers of change with actors and to build scenarios with them, with very limited supply of information from the research team. Three reasons guided this choice. Firstly, there was a paucity of data at local level to provide a sound basis for the research team to define scenarios (there was no accurate data on irrigated areas, no downscaled climate change model and no agreed upon aquifer groundwater balance). Secondly, the team posited that there was a risk that farmers with low level of literacy would not feel at ease to criticize and deconstruct a scenario proposed by researchers. Thirdly, such approach would enable the scenarios to be considered as a production jointly made with actors, who would later present them at the final meeting.

Such co-production in the Chaouia case was also thought as a means to face two possible stumbling blocks to fruitful discussion between public organizations and farmers, which had been spotted during the initial diagnosis. First, in public meetings, farmers often contended that, given existing trends, the only possible evolution was that intensive agriculture would have disappeared by 2020 . There was thus a risk that farmers would not depart from such discourse in the final meeting with public organizations. The team decided to identify with the farmers' groups possible positive future evolutions, both during workshops, and with parallel activities, such as the support over the reflection to create a milk collection cooperative. Second, staff of the Department of Agriculture faced difficulties to question the Regional Agricultural Plan both with colleagues and in front of farmers, although they had doubts about its relevance and effective implementation. The research team hypothesized that the foresight analysis could provide a space where these civil servants could, while acknowledging the possibility of the official scenario, freely imagine other possible futures. Eventually, in the final workshop, the actors presented the diverse scenarios they had produced with 
a visible sense of ownership, and this triggered an open atmosphere conducive to exchanges between both groups.

The Roussillon and Querença-Silves processes on one side and Chaouia one on the other side are thus situated at the two extremities of the above-mentioned gradient with regards to the source of information. These differences in the way scenarios were designed impacted also on their contents and status: agricultural development scenarios were more comprehensive and detailed in the Roussillon and Querença-Silves cases than in the Chaouia one. For instance, in Roussillon and Querença, the scenarios used in workshop 2 and 2' were embedded in a global economic scenario defined at European level, and the local socio-economic consequences of macro-level changes were described. Moreover, in the Roussillon and Querença-Silves sites, there was no aim to produce an action plan, so scenarios were used basically as a discussion support. What was important was not to choose a scenario, but to build a common understanding of major factors of change, trends and uncertainties, to explore possible consequences for agriculture of the contrasted economic and climatic assumptions expressed in the scenarios and to critically examine various groundwater regulation mechanisms. By contrast, In the Chaouia site, the scenarios were the production of local actors, and it was important for each group to define desirable scenarios as they provided the basis for an action strategy.

\section{Time frame in scenario building}

With regards to the time frame for foresight analysis, the choice of a specific horizon revolves around the need to build a common ground between the time frame of climate change models and the one that actors generally use to plan and make decisions, which is usually much shorter. Such common ground is usually set from 25 years ahead (Patel et al., 2007) to approximately 50 years ahead (Eakin et al., 2007). Another possibility is to progressively increase such time horizon with participants (Poumadère et al., 2008).

In the Roussillon and Querença-Silves cases, two time frames were used: 2030 for the first series of workshops and 2050 during the second and third series. Indeed, farmers easily entered the foresight exercise with a 20 year timeframe, which corresponds to the lifetime of many investments in agriculture, such as orchard plantation and irrigation equipment. It was then relatively easy for them to move 20 years forward to think about the consequences of climatic change on an agriculture, which they could already imagine as being different from what it is today.

In the Chaouia case, the time frame was much closer because, for both farmers and public organizations, it did not make sense to think at a distant time horizon. Farmers needed to react to changes in their environment (rainfall, markets, diseases, etc.) very rapidly and they grew only annual crops, so they faced difficulties to describe what would become their farm a number of years ahead. For public organizations it was also difficult to discuss at a remote time frame, since the Department of Agriculture had engaged in public policies which could have strong impacts on the region in the short term, but whose implementation was highly uncertain. Therefore, at even a horizon of 10 years, and given the high reactivity of the aquifer to imbalances between water uses and recharge, agriculture could follow very different pathways depending on the implementation of such public policies and rainfall patterns. Moreover, the lack of data for planning of regional development limited the possibility to define possible development scenarios at a more remote time horizon. 
Author-produced version of the article published in Regional Environmental Change, 2014, N ${ }^{\circ} 14$, p.57-70

The original publication is available at http://link.springer.com/article/10.1007\%2Fs10113-012-0362-x

Doi: 10.1007/s10113-012-0362-x

Obtaining information about the past appeared also to play an important role to engage in foresight analyses. The initial analysis of past evolution, in both the Chaouia and the Querença-Silves sites proved useful to establish a common understanding between researchers and farmers, as the latter often used the past as an importance reference point when imaging possible futures. It also helped realizing that change can be relatively fast. For instance, the reference that Portugal and Spain (as competitor of the Roussillon region for the latter) entered the European Union 30 years ago facilitated the exploration of the 2030-2050 period in the Roussillon case.

\section{Discussion}

\section{Elements taken into account for process design}

The teams took into account several elements to make choices for the four analyzed issues in process design (Fig 2). Most of the elements presented in Figure 2 were different among the cases (in particular those mentioned in Table 1), leading to different choices. Other elements are not represented in this figure, such as the position of the team locally.

The analysis made shows the importance of the uncertainties and risks that the teams associated with the alternatives they considered during process design. For instance, as much as the Chaouia team thought that it was risky to come with predefined scenarios to ask farmers to criticize them, the Roussillon team estimated that it was hazardous to ask actors to get involved in a lengthy co-design of agricultural development scenarios. Specific competencies of the researchers played also a role in the choices made. In particular, some researchers had previous experiences of foresight works and were more eager to use methods that they already mastered. This difference of backgrounds and preferred approaches led to intense discussion among team members, especially with regards the way to structure the debates around information brought by scientists or created with participants. 


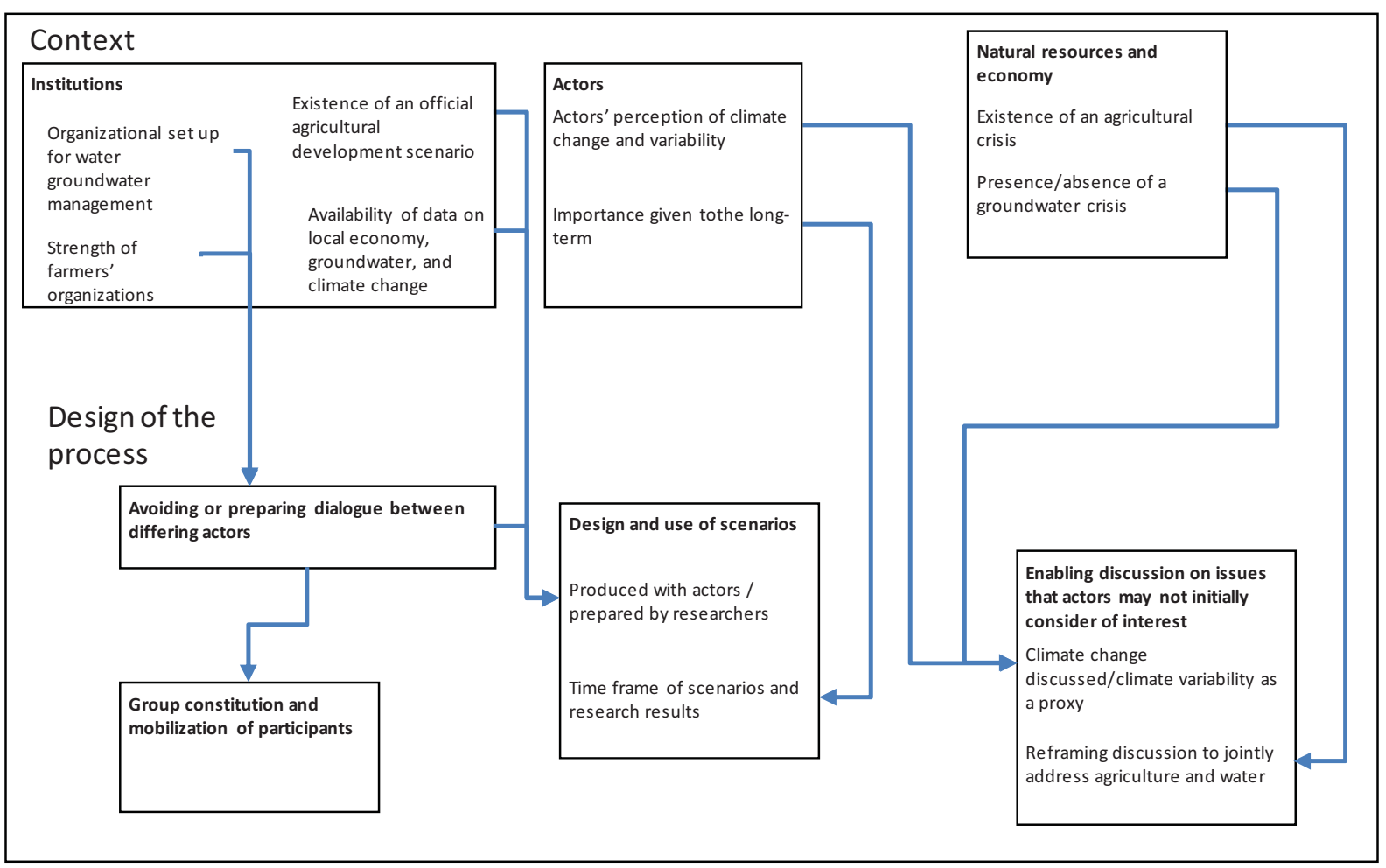

Fig. 2. Main links between context and choices in the design of the participatory processes

Lessons about how to critically "handle" the request for participatory reflection over adaptation to climate change

The flexibility in the choices during process design enabled to overcome the barriers to participatory analysis of climate change adaptation presented in the introduction and to discuss with actors about improving adaptation to climate change, in a more or less direct way depending on the cases. These choices first related to cognitive issues. In a similar way to other reflection processes over adaptation to climate change, they were about how to present information so that participants understand the climate change issue and consequences. In particular, in order to enable effective participation, depending on the context, choices made were of putting science analyses of climate change prospects up front or to keep it aside. The Aquimed processes were more specific in the attention paid to enroll actors in such reflection process, and to incorporate the climate change issue in a larger discussion framework depending on local contexts. The most extreme case was the Chaouia one, where a double reframing took place: addressing future climate change through current climate variability, and discussing adaptation to the groundwater crisis rather than groundwater management. Such reframing may be considered as part of the increasingly acknowledged need to embed (or "mainstream") the issue of climate change adaptation in local development policies (Chuku, 2010).

In the future, the interest (and available funds) for analyses of adaptation to climate change undertaken in a participatory way with local actors, is likely to remain strong. The discrepancy between donors' concern for long-term development issues and local actors more short-term preoccupations is also likely to remain. In that sense, the risk is, as always, to define and implement 
"participatory" processes around an agenda that has been defined by actors outside the local arena. Mainstreaming the climate change issue means then more than just addressing "extra" issues as required "detours" to later on address the climate change issue. It means that the climate change issue may not necessarily remain the core focus of the reflection process, and becomes an element of discussion, among many others, of a negotiated and agreed frame of discussion between actors, including researchers and, hopefully, donors. However, careful framing of a discussion agenda that includes climate change may not be sufficient to ensure that participatory planning exercises trigger sustained interactions between actors regarding development alternatives of local territories. While the careful preparation of a multi-actor final workshop in Portugal and Morocco showed the possibility of interesting exchanges, in the two cases, the limited capacities of both public organizations and farmers' organizations did not enable such sustained interaction after the end of research-led reflection processes.

\section{Conclusion}

The Aquimed experience showed the possibility of participatory analyses for adapting to climate change, in situations not initially propitious for such work. In particular, it showed, in the three studied cases, farmers' interest and capacity to engage in such kind of foresight reflection, despite the economic fragility of their sector and their lack of experiences in discussing such issues. Apart from some shortcomings, the choices made in process design showed the possibility to address the previously mentioned challenges to actors' participation in foresight analyses about adaptation to climate change. In a situation of deep agricultural crisis, the method supported actors in moving from a passive attitude in their reflection towards expected changes, to a more active one.

Four elements appear as key elements in these achievements. First, the teams made an initial analysis of the study areas that enabled to craft processes adapted to local contexts. This involved an assessment of a common set of criteria which included, among others, the institutions, actors, the status of natural resources and economy, and the skills and position of the researchers. Second, the duration of the processes enabled to build trust between research and participants, as well as to develop a common frame of understanding between them. Finally, the team had skills in group dynamics and capacities to work in an interdisciplinary way.

This diversity in chosen options also underlined the absence of a "one best way" in such type of participatory process. Indeed, in the past ten years, a large number of studies proposed an ever increasing range of methods to implement participatory discussion over adaptation to climate change at local level. There is thus concomitantly an increasing need for teams aiming at undertaking such types of process to explicitly understand how to make choices, given the diversity of situations they deal with, the diversity of existing methods, and their own goals, positions in local public arenas and competencies. In order to support such analysis, the proposed comparison of the Aquimed experiences is maybe not so much of interest for the case-specific choices and answers that were selected for each perceived stumbling block or risk since, as usual, there is limited scope for transferring one "recipe" from one situation to another one. This is all the more the case since, as much as the teams were not fully certain of the success of some choices at the time of process design, they were also not fully certain that other discarded options would necessarily lead to 
Author-produced version of the article published in Regional Environmental Change, 2014, N¹4, p.57-70

The original publication is available at http://link.springer.com/article/10.1007\%2Fs10113-012-0362-x

Doi: 10.1007/s10113-012-0362-x

shortcomings in process implementation. The added value of this comparative analysis is more to make explicit the way choices in the process design were made, and that are likely to be present in many of such types of participatory reflection processes that aim to include the climate change adaptation issue.

\section{Acknowledgments}

The study was conducted as part of the Aquimed project, funded in the framework of the Eranet Circle-Med initiative by the French Ministry of Ecology, Energy and Sustainable Development and the Portuguese Foundation for Science and Technology. In the Roussillon case, the workshops with public organizations were held with support from the Vulcain project.

\section{References}

Arnell NW (2004) Climate change and global water resources: SRES emissions and socio-economic scenarios. Glob Env Change 14, 31-52

Bento S, Driouech F, Errahj M, Faysse N, Garin, P, Richard Ferroudji, A, Rinaudo JD, Rollin D, Schmidt L, Varanda M (2009) Farmers' relations to climate variability and changes: the case of groundwater users of coastal aquifers in France, Portugal and Morocco. Paper presented at the 9th conference of the European Sociological Association, Lisbon, Sept, $3^{\text {rd }}$

Bento et al. (2012). Evaluation of the Aquimed process in the Querença-Silves region. Unpublished document.

Berrahmani A, Faysse N Errahj M, Gafsi M Submitted Chasing water: Diverging farmers' strategies to cope with the groundwater crisis in the coastal Chaouia region in Morocco

Chuku CA (2009) Pursuing an integrated development and climate policy framework in Africa: options for mainstreaming. Mitig Adapt Strateg Glob Change, 15:41-52

Commission of the European Communities (2007) Green Paper from the commission to the council, the European parliament, the European economic and social committee and the committee of the regions

Daniell, KA, Máñez Costa MA, Ferrand N, Kingsborough AB, Coad P, Ribaroba IS (2011) Aiding multilevel decision-making processes for climate change mitigation and adaptation. Reg Env Change 11: 243-258

Eakin H, Magaña V, Smith J, Moreno JL, Martínez JM, Landavazo O (2007) A stakeholder driven process to reduce vulnerability to climate change in Hermosillo, Sonora, Mexico. Mitig Adapt Strat Glob Change 12:935-955 
Author-produced version of the article published in Regional Environmental Change, 2014, No14, p.57-70 The original publication is available at http://link.springer.com/article/10.1007\%2Fs10113-012-0362-x Doi: 10.1007/s10113-012-0362-x

Faysse N, Errahj M, Imache A, Kemmoun H, Labbaci T (Submitted) When integrated water resource management stands too far away: participatory scenario building to initiate a dialogue on adaptation to the groundwater crisis in Morocco

Few R, Brown K, Tompkins E (2007) Public participation and climate change adaptation avoiding the illusion of inclusion. Climate Policy 7 (1):46-59

Gidley JM, Fien J, Smith JA, Thomsen DC, Smith TF (2009) Participatory futures methods: Towards adaptability and resilience in climate-vulnerable communities. Environmental Policy and Gov 19: $427-440$

Hulme M, Dessai S, Lorenzoni I., Nelson D (2009) Unstable climates: Exploring the statistical and social constructions of normal climate. Geoforum 40: 197-206

Imache A, Dionnet M, Bouarfa S, Jamin JY, Hartani T, Kuper M, Le Goulven P (2009) « Scénariologie participative ": une démarche d'apprentissage social pour appréhender l'avenir de l'agriculture irriguée dans la Mitidja. Cahiers Agricultures 18(5) : 417-424

Kock, IC, Vogel C, Patel Z (2007) Institutional dynamics and climate change adaptation in South Africa. Mitig Adapt Strat Global Change: 12(8): 1323-1339.

Kowalski K, Stagla S, Madlenerb R, Omannc I (2009) Sustainable energy futures: Methodological challenges in combining scenarios and participatory multi-criteria analysis. European J of Operational Res 197(3) 1063-1074

Lim B, Spanger-Siegfried E, Burton I, Malone E, Huq S (eds) (2005) Adaptation policy frameworks for climate change: developing strategies, policies, and measures. Cambridge University Press, New York

Loibl W, Walz A (2010) Generic regional development strategies from local stakeholders' scenarios the Montafon experience. Ecol and Soc 15(3): 3

Lorenzoni I, Nicholson-Cole S, Whitmarsh L (2007) Barriers perceived to engaging with climate change among the UK public and their policy implications. Global Env Change 17: 445-459

Lövbrand E, Linnér B-O, Ostwald, M (eds.) (2009). Climate Science and Policy Research. Conceptual and Methodological Challenges, CSPR Report No 09:03, Centre for Climate Science and Policy Research, Norrköping, Sweden

McCrum G, Blackstock K, Matthews K, Rivington M, Miller D, Buchan K (2009) Adapting to climate change in land management: The role of deliberative workshops in enhancing social learning. Environmental Policy and Gov 19: 413-426

Maton L, Richard-Ferroudji A, Rinaudo JD, Caballero Y, Rollin D, Garin P (2010) Que pensent les agriculteurs et les acteurs institutionnels des impacts du changement climatique sur l'agriculture des Pyrénées Orientales et des adaptations possibles ? Résultats d'une démarche participative. Unpublished document.

Meenawat H, Sovacool BK (2011) Improving adaptive capacity and resilience in Bhutan. Mitig Adapt Strateg Glob Change 16:515-533 
Author-produced version of the article published in Regional Environmental Change, 2014, N¹4, p.57-70 The original publication is available at http://link.springer.com/article/10.1007\%2Fs10113-012-0362-x Doi: 10.1007/s10113-012-0362-x

Mertz O, Mbow C, Reenberg A, Diouf A (2009) Farmers' perception of climate change and agricultural adaptation strategies in rural Sahel. Environmental Management 43:804-816

Mitchell T, van Maarten A, Villanueva, PS (2010) Assessing progress on integrating disaster risk reduction and climate change adaptation in development process. SCR discussion Paper No.2, Brighton: Institute of Development Studies, Strengthening Climate Resilience Programme

Montginoul M, Rinaudo JD (2009) Quels instruments pour gérer les prélèvements individuels en eau souterraine ? Le cas du Roussillon. Economie Rurale 310 (2) : 40-56

Morton JF (2007) The impact of climate change on smallholder and subsistence agriculture PNASS 104 (50): 19680-19685

Patel, M, Kok, K, Rothman, DS (2007) Participatory scenario construction in land use analysis: An insight into the experiences created by stakeholder involvement in the Northern Mediterranean. Land Use Policy 24, 546-561

Poumadère M, Mays M, Pfeifle G, Vafeidis AT (2008) Worst case scenario as stakeholder decision support: a 5- to 6-m sea level rise in the Rhone delta, France. Climatic Change 91:123-143

Richard-Ferroudji, A, Garin, P, Matignon, M, Maton, L, Rinaudo, JD, Rollin, D (2011) Engager des agriculteurs à répondre à l'injonction d'adapter la gestion de l'eau au changement climatique Discussion de la mise en œuvre d'ateliers de prospective avec des agriculteurs usagers des nappes du Roussillon (France) Ancey, V, Dedieu, B, Antona, M, Avelange, I, Azoulay, G, Darnhofer, I, Hubert, B, Lémerry, B (Eds), Acte du colloque agir en situation d'incertitude, 22-24 novembre 2010 Montpellier

Rinaudo JD, Maton L, Richard-Ferroudji A, Chazot S and Terrasson I (submitted) Combining scenario workshops with modelling to assess future irrigation water demand. Agricultural Water Management

Rinaudo JD, Montginoul M, Varanda M, Bento B (2012) Envisioning innovative groundwater regulation policies through scenario workshops in France and Portugal Irrigation and drainage

Rounsevell, MDA, Metzger, MJ (2010) Developing qualitative scenario storylines for environmental change assessment. Wiley Interdisciplinary Reviews: Climate Change 1(4): 606-619

Shisanya CA, Khayesi M (2007) How is climate change perceived in relation to other socioeconomic and environmental threats in Nairobi, Kenya? Climatic Change 85(3-4): 271-284

Somot S, Sevault F, Déqué $M$, Crépon M (2008) 21st century climate change scenario for the Mediterranean using a coupled atmosphere-ocean regional climate model. Glob and Planetary Change 63: 112-126

Stigter TY, Ribeiro L, Samper J, Fakir Y, Pisan, B, Tomé S, Nunes JP, Oliveira R, Hugman R, Monteiro JP, Silva A, Shapouri M, Fonseca L (2012) Comparative assessment of climate change impacts on coastal groundwater resources and dependent ecosystems in the Mediterranean. Reg Env Change: this issue.

Thompkins EL, Few R, Brown K (2008) Scenario-based stakeholder engagement: Incorporating stakeholders preferences into coastal planning for climate change. J of Environmental Management 88: 1580-1592 
Author-produced version of the article published in Regional Environmental Change, 2014, N${ }^{\circ} 14$, p.57-70 The original publication is available at http://link.springer.com/article/10.1007\%2Fs10113-012-0362-x Doi: 10.1007/s10113-012-0362-x

Valkering P, Van der Brugge R, Offermans A, Rijkens-Klomp N (2010) Scenario analysis of perspective change to support climat adaptation: lessons from a pilot study on Dutch river management. Reg Environmental Change 11(2): 229-241 